Jet Li 
For my mother, Luo Yuanhui and my father, Yu Hanhao 


\section{Jet $\mathrm{Li}$}

\section{Chinese Masculinity and \\ Transnational Film Stardom}

Sabrina Qiong Yu 
(C) Sabrina Qiong Yu, 2012

Edinburgh University Press Ltd

22 George Square, Edinburgh

www.euppublishing.com

Typeset in Monotype Ehrhardt by

Servis Filmsetting Ltd, Stockport, Cheshire, and

printed and bound in Great Britain by

CPI Group (UK) Ltd, Croydon, CR0 4YY

A CIP record for this book is available from the British Library

ISBN 9780748645473 (hardback)

ISBN 9780748645480 (webready PDF)

ISBN 9780748653836 (epub)

ISBN 9780748653829 (Amazon ebook)

The right of Sabrina Qiong Yu

to be identified as authors of this work

has been asserted in accordance with

the Copyright, Designs and Patents Act 1988. 